\title{
Maps, Figures, and Table
}

\section{Maps}

I.I The Southern Isthmus 2

I.2 Early and Late Postclassic site distributions 28

I.3 Relationship of the Panteón Antiguo archaeological site and the colonial Santa Cruz Tagolaba barrio 35

2.I Panteón Antiguo site administrative center, Santa Cruz Tagolaba barrio $\quad 44$

2.2 The palace complex at Guiengola 64

3.I The Tehuantepec province in the sixteenth century 98

3.2 Ground plan of the Tehuantepec church and convent complex

Figures

I. I García version of the Lienzo de Guevea I2

I.2 Petapa I version of the Lienzo de Guevea I6

I.3 Guevea I and Petapa I royal genealogies for the Zaachila and Tehuantepec kings $\quad$ I8

I.4 Representation of I I Water, "Obsidian Knife Rain Storm," Xipe dynasty ruler of Zaachila, and his son 6 Water, "Colored Strips,"in the precolumbian Mixtec manuscript, the Codex Zouche Nuttall 20

I.5 Genealogy of the Xipe Dynasty royal family at Zaachila 2I

I.6 Early Postclassic pottery styles 30

I.7 Late Postclassic gray ware pottery 3 I 
x / Maps, Figures, and Table

I.8 View of the ruins of Guiengola by Miguel Covarrubias 34

2.I I 580 Relación Geográfica map of the Tehuantepec province 4 I

2.2 Tribute record sheets from the I 553 criminal complaint against Don Juan Cortés, governor of Tehuantepec $\quad 46$

2.3 The Mapa de Huilotepec 60

2.4 The Mapa de Huilotepec, detail of the upper register 6I

3.I Drawing of abuses suffered by Mexican Indian residents of Tehuantepec accompanying their I 553 criminal complaint against Don Juan Cortés, governor of Tehuantepec $\quad$ IO3

3.2 Depiction of abuses suffered by Zapotec complainants under Don Juan Cortés, governor of Tehuantepec $\quad$ IO4

3.3 The Tehuantepec church IIO

$\begin{array}{ll}\text { 4.I The Chihuitán church } & \text { I23 }\end{array}$

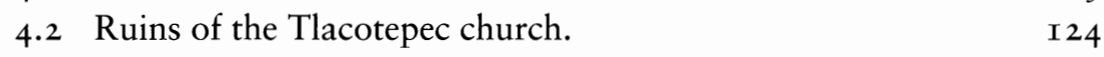

4.3 Excavations at Rancho Santa Cruz $\quad$ I 28

4.4 Land requests and grants awarded to non-natives during the $\begin{array}{ll}\text { Tehuantepec ranching boom } & \text { I } 38\end{array}$

4.5 Land requests and grants awarded to natives during the $\begin{array}{ll}\text { Tehuantepec ranching boom } & \text { I47 }\end{array}$

4.6 Iron nails from Rancho Santa Cruz excavations $\quad$ I 56

4.7 Majolica pottery sherds from Rancho Santa Cruz
excavations

4.8 Colonial-period Tablón Orange pottery $\quad$ I60

6.I Age distribution of the Isthmus Zapotec population in I722 2 I 2

7.I The Tehuantepec/San Francisco del Mar cacicazgo genealogies

Table

6.I Rank order by total population of Zapotec-speaking urban barrios and rural communities in $\mathbf{1} 722$ 